\title{
European Thyroid Journal
}

\section{Editor-in-Chief}

Wilmar M. Wiersinga, Amsterdam

\section{Associate Editors}

Josef Koehrle, Berlin

(Basic Thyroidology)

Peter Laurberg, Aalborg

(Clinical Thyroidology)
Luca Persani, Milan

(Translational Thyroidology)

Furio Pacini, Siena

(Thyroid Cancer)

\section{Editorial Board}

Maria Alevizaki, Athens

Ana Aranda, Madrid

Rebecca Bahn, Rochester, Minn.

Paul Banga, London

Luigi Bartalena, Varese

Bernadette Biondi, Naples

Anita Boelen, Amsterdam

Georg Brabant, Lübeck

Henning Dralle, Halle

Creswell J. Eastman, Westmead, N.S.W.

Murat Erdogan, Ankara

Valentin Fadeyev, Moscow

Ulla Feldt-Rasmussen, Copenhagen

Laszlo Hegedus, Odense

George J. Kahaly, Mainz

Rui Maciel, São Paolo

Ana Luiza Maia, Porto Alegre
Jens Mittag, Stockholm

Ralf Paschke, Leipzig

Simon Pearce, Newcastle-upon-Tyne

Robin Peeters, Rotterdam

Kris Poppe, Bruxelles

Samuel Refetoff, Chicago, Ill.

Jacques Samarut, Lyon

Pilar Santisteban, Madrid

YoungKee Shong, Seoul

Jan Smit, Leiden

Weiping Teng, Shenyang

Mark Vanderpump, London

Theo Visser, Rotterdam

Paolo Vitti, Pisa

Graham Williams, London

Shunichi Yamashita, Nagasaki

Mariastella Zannini, Naples 


\section{European \\ Thyroid Journal}

No. 1

\section{Editorials}

1 The European Thyroid Journal in Its Third Year of Publication: A Thriving Enterprise Wiersinga, W.M. (Amsterdam)

3 lodine Status in Europe in 2014

Lazarus, J.H. (Cardiff)

Commentary

7 Classification and Proposed Nomenclature for Inherited Defects of Thyroid Hormone Action, Cell Transport, and Metabolism

Refetoff, S. (Chicago, Ill.); Bassett, J.H.D. (London); Beck-Peccoz, P. (Milan); Bernal, J. (Madrid); Brent, G. (Los Angeles, Calif.); Chatterjee, K.

(Cambridge); De Groot, L.J. (South Dartmouth, Mass.); Dumitrescu, A.M (Chicago, Ill.); Jameson, J.L. (Philadelphia, Pa.); Kopp, P.A. (Chicago, Ill.); Murata, Y. (Nagoya); Persani, L. (Milan); Samarut, J. (Lyon); Weiss, R.E. (Chicago, Ill.); Williams, G.R. (London); Yen, P.M. (Singapore)

Translational Thyroidology

Original Paper

10 Persistent Cellular Metabolic Changes after Hemithyroidectomy for Benign Euthyroid Goiter

Toft Kristensen, T. (Køge); Larsen, J.; Pedersen, P.L.; Feldthusen, A.-D.; Ellervik, C. (Næstved); Jelstrup, S. (Køge); Kvetny, J. (Næstved)

\section{Clinical Thyroidology}

Reviews

17 Clinical Consequences of Mutations in Thyroid Hormone Receptor-a1

van Mullem, A.A.; Visser, T.J.; Peeters, R.P. (Rotterdam)

25 Selenium Supplementation for Hashimoto's Thyroiditis: Summary of a Cochrane Systematic Review

van Zuuren, E.J. (Leiden); Albusta, A.Y. (Manama); Fedorowicz, Z. (Awali); Carter, B. (Cardiff); Pijl, H. (Leiden)

\section{Original Papers}

32 Major Haemorrhage during Vitamin K Antagonist Treatment: The Influence of Thyroid Hormone Levels

Debeij, J.; Cannegieter, S.C. (Leiden); van Zaane, B.; van Zanten, A.P. (Amsterdam); Rosendaal, F.R. (Leiden); Gerdes, V.E.A. (Amsterdam); Reitsma, P.H.; Dekkers, O.M. (Leiden)

38 Thyroid Tubercle of Zuckerkandl Is More Consistently Present and Larger on the Right: A Prospective Series

Mehanna, R.; Murphy, M.S.; Sheahan, P. (Cork)
43 Basal Serum Thyroglobulin Measured by a SecondGeneration Assay Is Equivalent to Stimulated Thyroglobulin in Identifying Metastases in Patients with Differentiated Thyroid Cancer with Low or Intermediate Risk of Recurrence Nakabashi, C.C.D.; Kasamatsu, T.S.; Crispim, F.; Yamazaki, C.A.; Camacho, C.P.; Andreoni, D.M.; Padovani, R.P.; Ikejiri, E.S.; Mamone, M.C.O.M.; Aldighieri, F.C.; Wagner, J.; Hidal, J.T.; Vieira, J.G.H.; Biscolla, R.P.M.; Maciel, R.M.B. (São Paulo)

51 A Rare Case of Dyshormonogenetic Fetal Goiter Responding to Intra-Amniotic Thyroxine Injections Khamisi, S.; Lindgren, P.; Karlsson, F.A. (Uppsala)

57 Pathology-Proven Inguinal Node Metastasis from Papillary Thyroid Cancer in a Male without Disease below the Diaphragm Mari Aparici, C.; Liu, T. (San Francisco, Calif.)

60 Coexistence of Thyroid-Stimulating Hormone-Secreting Pituitary Adenoma and Graves' Hyperthyroidism Kamoun, M.; d'Herbomez, M. (Lille); Lemaire, C. (Béthune); Fayard, A. (Lille); Desailloud, R. (Amiens); Huglo, D.; Wemeau, J.-L. (Lille)

65 Thyrotoxicosis followed by Hypothyroidism due to Suppurative Thyroiditis Caused by Nocardia brasiliensis in a Patient with Advanced Acquired Immunodeficiency Syndrome Teckie, G.; Bhana, S.A.; Tsitsi, J.M.L.; Shires, R. (Johannesburg)

69 Occurrence of De Quervain's Thyroiditis after Resolution of Hypercortisolism following Pasireotide Treatment for Cushing's Disease and Surgery for an Adrenocortical Adenoma: Report of Two Cases Efstathiadou, Z.A.; Sykja, A.; Anagnostis, P.; Panagiotou, A.; Kita, M. (Thessaloniki)

\section{No. 2}

\section{Editorial}

73 Subclinical Hypothyroidism and Pregnancy: The Intersection of Science, the Art of Medicine, and Public Health Policy Stagnaro-Green, A. (Rockford, Ill.)

Guidelines

762014 European Thyroid Association Guidelines for the Management of Subclinical Hypothyroidism in Pregnancy and in Children

Lazarus, J. (Cardiff); Brown, R.S. (Boston, Mass.); Daumerie, C. (Brussels); Hubalewska-Dydejczyk, A. (Krakow); Negro, R. (Lecce); Vaidya, B. (Exeter)

Basic Thyroidology

Review

95 Historical Note: Many Steps Led to the 'Discovery' of Thyroid-Stimulating Hormone

Magner, J. (Cambridge, Mass.)

\section{KARGER}

E-Mail karger@karger.com www.karger.com
(C) 2014 S. Karger AG, Basel

Access to full text and tables of contents, including tentative ones for forthcoming issues: www.karger.com/etj_issues 
Translational Thyroidology

Original Paper

101 The TRHR Gene Is Associated with Hypothalamo-Pituitary Sensitivity to Levothyroxine

Brigante, G.; Spaggiari, G.; Santi, D.; Cioni, K.; Gnarini, V.; Diazzi, C.; Pignatti, E.; Casarini, L.; Marino, M. (Modena); Tüttelmann, F. (Munster);

Carani, C.; Simoni, M. (Modena)

Clinical Thyroidology

Original Papers

109 A Progress Report of the IFCC Committee for Standardization of Thyroid Function Tests

Thienpont, L.M.; Van Uytfanghe, K.; Van Houcke, S. (Gent); Das, B. (Mumbai); Faix, J.D. (Palo Alto, Calif.); MacKenzie, F. (Birmingham); Quinn, F.A. (Abbott Park, Ill.); Rottmann, M. (Penzberg); Van den Bruel, A. (Bruges) for the IFCC Committee for Standardization of Thyroid Function Tests (C-STFT)

117 Development and Application of a Novel Sensitive Immunometric Assay for Calcitonin in a Large Cohort of Patients with Medullary and Differentiated Thyroid Cancer, Thyroid Nodules, and Autoimmune Thyroid Diseases

Camacho, C.P.; Lindsey, S.C.; Kasamatsu, T.S.; Machado, A.L.; Martins, J.R.M.; Biscolla, R.P.M.; Dias da Silva, M.R.; Vieira, J.G.H.; Maciel, R.M.B. (São Paulo)

125 Recombinant Human Thyrotropin Use Resulting in Ovarian Hyperstimulation: An Unusual Side Effect Rizvi, T.; Rehm, P.K. (Charlottesville, Va.)

130 Simple Core-Needle Biopsy for Thyroid Nodule, Complicated Tinnitus Bergeron, M.; Beaudoin, D. (Quebec, Que.)

134 lodophilic Synchronous Phalangeal and Choroidal Metastasis from Follicular Thyroid Carcinoma: A Case Report and Review Patil, D.; Kumaraswamy Kattepur, A.; Kodaganur Gopinath, S.; Swamy, S.; Shankarappa, A.; Kodaganur Srinivasachar, G. (Bangalore)

Letters to the Editor

137 The Dilemma of Treating Subclinical Hypothyroidism: Risk that Current Guidelines Do More Harm than Good Stott, D.J. (Glasgow); Bauer, D.C. (San Francisco, Calif.); Ford, I (Glasgow); Kearney, P. (Cork); Gussekloo, J. (Leiden); Quinn, T.J. (Glasgow); Rodondi, N. (Bern); Smit, J. (Nijmegen); Westerdorp, R. (Leiden)

139 Reply on the Letter by Stott et al. 'The Dilemma of Treating Subclinical Hypothyroidism: Risk that Current Guidelines Do More Harm than Good'

Duntas, L.H. (Athens); Brabant, G. (Lübeck); Monzani, F. (Pisa,);

Pearce, S.H.S. (Newcastle upon Tyne); Peeters, R.P. (Rotterdam); Razvi, S (Newcastle upon Tyne/Gateshead); Wemeau, J.-L. (Lille)

141 Letter regarding the Paper by Pearce et al. Entitled '2013 ETA Guideline: Management of Subclinical Hypothyroidism'

Mooijaart, S.P. (Leiden) on behalf of the IEMO 80-plus Thyroid Trial Collaboration

\section{No. 3}

Basic Thyroidology

Review

143 Structure and Function of Thyroid Hormone Plasma Membrane Transporters

Schweizer, U. (Bonn); Johannes, J. (Berlin); Bayer, D.; Braun, D. (Bonn)
Clinical Thyroidology

Review

154 Thyroid Incidentalomas: Epidemiology, Risk Stratification with Ultrasound and Workup

Russ, G. (Paris); Leboulleux, S. (Villejuif); Leenhardt, L. (Paris); Hegedüs, L (Odense)

Original Papers

164 Spontaneous Abortion, Stillbirth and Hyperthyroidism: A Danish Population-Based Study

Andersen, S.L. (Aalborg); Olsen, J.; Wu, C.S. (Aarhus); Laurberg, P. (Aalborg)

173 Anxiety and Depression Are More Prevalent in Patients with Graves' Disease than in Patients with Nodular Goitre Bové, K.B.; Watt, T.; Vogel, A. (Copenhagen); Hegedüs, L. (Odense); Bjoerner, J.B.; Groenvold, M. (Copenhagen); Bonnema, S.J. (Odense); Rasmussen, Å.K.; Feldt-Rasmussen, U. (Copenhagen)

179 Challenges in the Evaluation of Urinary lodine Status in Pregnancy: The Importance of lodine Supplement Intake and Time of Sampling

Andersen, S.L.; Sørensen, L.K.; Krejbjerg, A.; Møller, M.; Laurberg, P. (Aalborg)

189 Environmental, Lifestyle, and Anthropometric Risk Factors for Differentiated Thyroid Cancer in Cuba: A Case-Control Study Lence-Anta, J.J. (Havana); Xhaard, C. (Villejuif); Ortiz, R.M. (Havana); Kassim, H. (Villejuif); Pereda, C.M.; Turcios, S.; Velasco, M.; Chappe, M.; Infante, I.; Bustillo, M.; García, A. (Havana); Clero, E.; Maillard, S. (Villejuif); Salazar, S.; Rodriguez, R. (Havana); de Vathaire, F. (Villejuif)

197 Evolution of Differentiated Thyroid Cancer: A Decade of Thyroidectomies in a Single Institution Zafon, C.; Baena, J.A.; Castellví, J.; Obiols, G.; Gonzalez, O.; Fort, J.M.; Vilallonga, R.; Caubet, E.; Armengol, M.; Mesa, J. (Barcelona)

202 Small Lymphocytic Lymphoma of the Thyroid Mimicking Plasmacytoma

Gill, M.; Batra, A.; Sangwaiya, A. (Rohtak); Shakya, S. (Sirsa); Gupta, S.; Sen, R. (Rohtak)

206 Myasthenic Crisis Manifesting as Postoperative Respiratory Failure following Resection of Unsuspected Intrathoracic Thymic T-Cell Lymphoma during Thyroidectomy for an Adjacent Large Retrosternal Goiter Ahmed, M.E.; Mahgoub, M.A.; Alnedar, M.G.; Mahadi, S.I.; Alzubeir, M.; El Hassan, L.A.M.; Elamin, E.M.; El Hassan, A.M. (Khartoum)

No. 4

Basic Thyroidology

Original Paper

211 CBX7 Expression in Oncocytic Thyroid Neoplastic Lesions (Hürthle Cell Adenomas and Carcinomas)

Monaco, M.; Chiappetta, G.; Aiello, C.; Federico, A.; Sepe, R.; Russo, D. (Naples); Fusco, A. (Naples/Rio de Janeiro); Pallante, P. (Naples)

Translational Thyroidology

Review

217 Platelet-Derived Growth Factor: A Key Factor in the Pathogenesis of Graves' Ophthalmopathy and Potential Target for Treatment

Virakul, S.; van Steensel, L.; Dalm, V.A.S.H. (Rotterdam); Paridaens, D. (Rotterdam/Geneva); van Hagen, P.M.; Dik, W.A. (Rotterdam)

Original Paper 
227 Novel NKX2-1 Frameshift Mutations in Patients with Atypical Phenotypes of the Brain-Lung-Thyroid Syndrome de Filippis, T.; Marelli, F.; Vigone, M.C.; Di Frenna, M.; Weber, G.; Persani, L. (Milan)

Clinical Thyroidology

Original Papers

234 Population Reference Values and Prevalence Rates following Universal Screening for Subclinical Hypothyroidism during Pregnancy of an Afro-Caribbean Cohort

Johnson, N.; Chatrani, V.; Taylor-Christmas, A.-K.; Choo-Kang, E.; Smikle, M.; Wright-Pascoe, R.; Phillips, K.; Reid, M. (Kingston)

240 A Conservative Approach Is Reasonable in Patients with Non-Toxic Goitre: Results from an Observational Study during 30 Years

Järhult, J. (Eksjö/Jönköping); Vedad, R. (Jönköping)

245 Patient Knowledge of Antithyroid Drug-Induced Agranulocytosis

Robinson, J.; Richardson, M. (Newcastle upon Tyne); Hickey, J. (Harrogate) James, A.; Pearce, S.H.; Ball, S.G.; Quinton, R.; Morris, M.; Miller, M.; Perros, P. (Newcastle upon Tyne)

252 Cervical Lymph Nodes, Thyroiditis and Ophthalmopathy: The Pleomorphic Face of an Immunoglobulin G4-Related Disease

Ghys, C.; Depierreux, M.; Ozalp, E.; Velkeniers, B. (Brussels)

258 Retrospective Analysis of $\mathbf{2 5 5}$ Papillary Thyroid Carcinomas $\leq \mathbf{2 c m}$ : Clinicohistological Features and Prognostic Factors Marques, P.; Leite, V.; Bugalho, M.J. (Lisbon)
264 Recombinant Human Thyroid-Stimulating Hormone-Aided Remnant Ablation Achieves a Response to Treatment Comparable to That with Thyroid Hormone Withdrawal in Patients with Clinically Relevant Lymph Node Metastases Pitoia, F.; Abelleira, E.; Cross, G. (Buenos Aires)

272 Tandem Germline RET Mutations in a Family Pathogenetic for Multiple Endocrine Neoplasia 2B, Confirmed by a Natural Experiment

Kihara, M.; Miyauchi, A.; Yoshida, H.; Yamada, O.; Masuoka, H.; Yabuta, T. Higashiyama, T.; Fukushima, M.; Ito, Y.; Kobayashi, K.; Miya, A. (Kobe)

278 Anaplastic Carcinoma and Toxic Multinodular Goiter: An Unusual Presentation

Marcelino, M.; Marques, P.; Lopes, L.; Leite, V.; de Castro, J.J. (Lisbon)

283 Author Index Vol. 3, 2014

284 Subject Index Vol. 3, 2014

\section{Suppl. 1}

38th Annual Meeting of the European Thyroid Association Programme and Abstracts

Santiago de Compostela, Spain, September 6-10, 2014

Guest Editors: F. Pacini, (Siena); C.V. Alvarez (Santiago de Compostela)
S. Karger

Medical and Scientific Publishers

Basel $\cdot$ Freiburg $\bullet$ Paris $\bullet$ London .

New York $\cdot$ Chennai $\cdot$ New Delhi $\cdot$

Bangkok $\cdot$ Beijing $\cdot$ Shanghai $\cdot$ Tokyo $\cdot$

Kuala Lumpur $\cdot$ Singapore $\cdot$ Sydney

\begin{abstract}
Disclaimer
The statements, opinions and data contained in this publication are solely those of the individual authors and contributors and not of the publisher and the editor(s). The appearance of advertisements in the journal is not a warranty, endorsement, or approval of the products or services advertised or of their effectiveness, quality or safety. The publisher and the editor(s) disclaim responsibility for any injury to persons or property resulting from any ideas, methods, instructions or products referred to in the content or advertisements.

Drug Dosage

The authors and the publisher have exerted every effort to ensure that drug selection and dosage set forth in this text are in accord with current recommendations and practice at the time of publication. However, in view of ongoing research, changes in government regulations, and the constant flow of information relating to drug therapy and drug reactions, the reader is urged to check the package insert for each drug for any change in indications and dosage and for added warnings and precautions. This is particularly important when the recommended agent is a new and/or infrequently employed drug.
\end{abstract}

All rights reserved.

No part of this publication may be translated into other languages, reproduced or utilized in any form or by any means electronic or mechanical, including photocopying, recording, microcopying, or by any information storage and retrieval system, without permission in writing from the publisher or, in the case of photocopying, direct payment of a specified fee to the Copyright Clearance Center (see 'General Information').

(C) Copyright 2013/2014 by S. Karger AG,

CH-4009 Basel (Switzerland)

Printed on acid-free and non-aging paper (ISO 9706) 